\title{
MR. JUSTICE BLACK AND THE SUPREME COURT
}

\author{
VINCENT M. BARNETT, JR.*
}

$\mathrm{B}^{\mathrm{s}}$ ECAUSE of the circumstances surrounding his accession to the bench, the career of Hugo Lafayette Black as Associate Justice of the Supreme Court of the United States has been of more than usual public interest. Much of that interest has centered around criticisms which are unworthy of their subject. It must be said at the outset that this article is not primarily an attempt to defend Justice Black's ability; in the three years that he has been a member of the Court he has demonstrated that he is fully qualified to perform his duties, and today his record on constitutional issues is already of considerable significance. Mr. Justice Black's appointment to the bench marked the beginning of an important change in the Court's attitude as to what the Constitution requires of the federal judiciary; a change involving greater judicial restraint in dealing with legislation and also a restriction in the scope of the jurisdiction of the federal judiciary in dealing with the concerns of the several states. At first this change was only a surgence, expressed in Black's dissenting opinions; but with the appointment of Justices Reed, Frankfurter, Douglas, and Murphy, the change began to find expression in majority opinions. ${ }^{\mathrm{I}}$ Justice Black's role during this period has been a major one, and a study of his opinions aids materially in gaining an insight into the political and social theory behind the change-a change which in many ways is a resurgence of the constitutional views of Jefferson and Madison.

Unfavorable publicity attending President Roosevelt's choice of Senator Black for the Supreme Court, together with the number of dissenting opinions rendered by the new Justice during his first term on the bench, inspired various attacks questioning the wisdom of the appointment. To the extent that these attacks were upon Black's intellectual capacity to serve as a judge, they require no detailed consideration here. It has been

* Instructor in Political Science, Williams College.

I During Black's first two years on the bench, the Court considered I 26 cases involving constitutional issues. Black dissented thirteen times and indicated his separate concurrence seventeen times. In other words, in thirty cases-approximately 24 per cent of the time-he disagreed with either the ruling or the reasons of the majority. In the I939 term, Black dissented but twice, and only once did he indicate a separate concurrence with the decision of the majority. 
said that Black's admittedly able constitutional opinions must have been ghost-written by some good lawyer. ${ }^{2}$ This and similar charges have been discussed and disposed of by other observers. ${ }^{3}$ It has also been said that New Dealer Black, on the bench, has fashioned his constitutional views to suit the exigencies of the course of New Deal politics. ${ }^{4} \mathrm{Mr}$. Justice Black's record as United States Senator indicates, however, that the views he expresses in his opinions are not built upon mere ephemeral political considerations, but are the expression of a deep-rooted constitutional philosophy. Whether the judgment of a justice of the Supreme Court should be based upon a constitutional philosophy differing in any great degree from that of his immediate predecessors is, however, a different question; and while it is true that this charge of lack of "judicial temperament" is usually made by those whose real disagreement is with the constitutional philosophy itself, the charge nevertheless has some foundation in respected theories as to the nature of the judicial function. The charge can best be discussed after a consideration of the cases.

Before turning to the opinions of Justice Black, however, it will be useful to survey the record of Senator Black; for that record expresses the man's views perhaps even more clearly than the judicial opinions. His basic principles - a Jacksonian distrust of entrenched privilege and corporate greed, a firm belief in the prerogatives of legislatures as the representative organs in a democracy, and an aversion to judicial encroachment upon the spheres of administrative and legislative actionthese principles were clearly set forth during his terms in the Senate. His views on constitutional power have always been influenced by the conviction that the Constitution must and does provide authority for effective and progressive government. As early as I 930 his opposition to utility exploitation of the consumer and his belief in vigorous and effective public regulation were matters of public knowledge. ${ }^{5}$ As the moving figure in

\footnotetext{
2 Referring to Black's dissenting opinion in McCart v. Indianapolis Water Co., 302 U.S. 4I9 (r937), discussed infra p. 33, Newsweek reported: "Lawyers agreed that the dissent was ably written. . . . . To many who questioned Black's legal knowledge, this opinion had the earmarks of ghost-writing. A rumor got around and even into print that it was the work of Tom Corcoran, ace New Deal lawyer, expert on utilities, and close friend of the new Justice." Ir Newsweek, No. 21, at 26 (May 23, I938). See also Lerner, Justice Black Dissenting, 146 Nation 264 (March 5, 1938).

${ }^{3}$ See, e.g., Hamilton, Mr. Justice Black's First Year, 95 New Republic Ir8 (June 8, I938); Curtis, How about Hugo Black?, I63 Atlantic Monthly 667 (May, I939); Lerner, Hugo Black: A Personal History, 145 Nation 367 (October 8, I937); Lerner, Justice Black Dissenting, $1_{4} 6$ Nation 264 (March 5, 1938.)
}

4 See, e.g., Childs, The Supreme Court Today, r76 Harpers 58I (May, 1938).

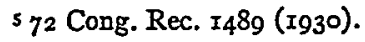


the well-remembered Senatorial investigation into lobbying by public utilities he later identified himself more completely with these views. ${ }^{6}$ And as early as I930 he attacked the unfair profits and "undesirable concentration of wealth" in these utilities, remarking that "plunder of the many seems to have become the privilege of the few."7 Furthermore, it was his view that the Fourteenth Amendment was not intended to impose a restriction upon the power of states to regulate the activities of public utility and other corporations. In a Senate speech in I935 on an anti-lynching measure he had occasion to refer to his study of the Fourteenth Amendment. "I found," he remarked, "that although the Fourteenth Amendment was intended to protect members of the colored race, it had served to protect not them, except in a very few instances, but it had served to protect corporate greed and cupidity. It had served, as we all know, to paralyze the arms of the States of the Union in their efforts to protect the people from corporate cupidity." "8

His insistence upon broad powers for the states, however, was coupled with a belief in a strong national government, in those fields where Congress chose to act. He early indicated his adherence to a broad interpretation of the commerce clause, saying that Congress' power to regulate interstate commerce is "supreme, as it would be in any single state." One of the main obstacles in the way of governments' attempts to meet changed conditions, he felt, was the usurpation of legislative power by judges. His notion that representative government requires a great deal of restraint on the part of courts in dealing with the activities of state and national legislative and administrative bodies found constant expression in his senatorial utterances. The Constitution should not be "so misinterpreted and altered as to shackle the democratic processes themselves,",10 for it was such "judicial tinkering with the Constitution" which "took from the people of my state and of every other state the right of their legislative representatives to regulate public utility rates except on condition that the state shall be brought all the way to the Supreme Court in Washington for that Court to pass on a reasonable profit."rr This process, he felt, "amounted to a clear usurpation of legislative power by the judges, changed the basic theory of our Constitution, .... protected wealth at

${ }^{6}$ See Black, Inside a Senate Investigation, I72 Harpers 275 (February, I936).

772 Cong. Rec. $4469-70$ ( 1930 ).

879 Cong. Rec. 6359 (1935).

9 This statement was made during the argument on the regulation of the petroleum industry, January, I935. 79 Cong. Rec. 757-58 (r935).

so 8r Cong. Rec. App. 307 (I937).

Ix Ibid. This was a radio address of February 23, I937, read into the record. 
the expense of poverty, . . . stripped the states of their powers and transferred these powers to the dominant five or six judges." "Iz It was a process which was "gradually and sometimes silently (as Jefferson said) absorbing to the federal judiciary, the only governmental department not responsible to the people, all the legislative rights of States and Federal Government." ${ }^{\prime 3}$ Republican government was not strengthened, he felt, by such assumption of power by courts.

\section{INTEGRATION OF STATE AND NATIONAL POWERS}

Some of Black's most significant comments as a Supreme Court Justice have been made upon the problem of the integration of state and national powers in a federal system. He has emphasized his belief in a kind of federalism which would grant a wide field of action to the states when the national government has not acted, but one which would also give Congress broad powers where it chooses to act. Thus, Black has attempted to free state legislatures from many of the restrictions of the Fourteenth Amendment as heretofore interpreted and from the implied limitations of the commerce clause. At the same time, however, this increase in state power does not mean a corresponding decrease in national power. The national power, when exercised, Black is willing to uphold in its broadest terms. Conflicting state legislation is, of course, void. ${ }^{x 4} \mathrm{An}$ examination of his opinions on state legislation, on the extent of commerce clause powers, and the scope of the jurisdiction of the federal courts, will help to clarify this position.

In the twenty-nine cases involving state tax laws coming before the Court during his three years on the bench, Black has voted only once to invalidate a statute. In this instance, moreover, only a partial invalidation was required and a relatively unimportant issue was involved. ${ }^{15}$ In most of the cases concerning the Fourteenth Amendment and the taxing power of the states, the Court ruled to uphold the tax in question. In such instances Black merely went along with the majority. ${ }^{\mathbf{1 6}}$ In a few

128 I Cong. Rec. App. 306 (1937).

${ }_{3} 8$ I Cong. Rec. App. 307 (I937).

${ }_{4}$ See, e.g., Black's remark in Gwin Co. v. Henneford upholding the "sound position that state laws are not invalid under the commerce clause unless they actually discriminate against interstate commerce or conflict with a regulation enacted by Congress." 305 U.S. 434, 446 (1939). The intimation is clear that in the event of such conflict, the law would be invalid.

s5 Collins v. Yosemite Park \& Curry Co., 304 U.S. $5^{\mathrm{I} 8}$ (I938), concerned a California tax on liquor sales made in Yosemite National Park, and a state license fee to sell or import liquor into the park. The former was held valid, the latter invalid, in a unanimous opinion written by Justice Reed.

${ }^{6}$ Breedlove v. Suttles, 302 U.S. 277 (I937); Schuylkill Trust Co. v. Pennsylvania, 302 U.S. 506 (I937); Guaranty Trust Co. v. Virginia, 305 U.S. I9 (I938); Welch v. Henry, 305 U.S. 134 
cases he indicated some divergence from the views of the majority by concurring separately without opinion, but he did not express himself in a written opinion so long as the laws in question were ruled valid. ${ }^{17}$ In a number of dissenting opinions Black has differed from the majority of the Court as to the extent to which the commerce clause is an implied restriction upon the state taxing power. His practical experience with legislative problems had led him to believe that courts are unable-except within certain broad limits - to set up satisfactory criteria in these cases; consequently, he insisted that the problem was for Congress to enact legislation aimed at integrating competing tax systems, and that until Congress had done so the Supreme Court should permit the states a broad degree of freedom. In Adams Mfg. Co. v. Storen ${ }^{18}$ an Indiana gross income tax as applied to income derived from sales in other states was ruled unconstitutional, as constituting a burden on interstate commerce. In a long dissenting opinion Black pointed out that the tax was general in effect, that it did not discriminate against interstate commerce, and that it fell uniformly on all gross incomes. Nor did it contravene any law of Congress. He deplored the striking down of the statute because of "merely possible future unfair burdens," and concluded:

Until Congress, in the exercise of its plenary power over interstate commerce, fixes a different policy, it would appear desirable that the States should remain free to adopt tax systems imposing uniform and non-discriminatory taxes upon interstate and intrastate business alike. ${ }^{x}$

Again in Grein Co. v. Henneford ${ }^{20}$ Black dissented from a majority opinion holding invalid a Washington tax on gross receipts from the business of marketing fruit shipped in interstate and foreign commerce. He asserted that the statute imposed a general, non-discriminatory tax measured by gross receipts upon all business operating in the state. He agreed with the majority as to the possible dangers in waiting for Congress to act, but he thought that the national legislature was the agency responsible for remedying them when they arose.

It is essential today, as at the time of the adoption of the Constitution, that commerce among the states and with foreign nations be left free from discriminatory and

(I938); Felt \& Tarrant Co. v. Gallagher, 306 U.S. 62 (I939); Pacific Tel. \& Tel. Co. v. Gallagher, 306 U.S. I82 (I939); Curry v. McCandless, $3 \circ 7$ U.S. 357 (I939); Graves v. Elliott, 307 U.S. 383 (I939); Pearson v. McGraw, 308 U.S. 3 I3 (I939); Ford Motor Co. v. Beauchamp, 308 U.S. 33 I (I939); Madden v. Kentucky, 309 U.S. 83 (r940); Illinois Central R. Co. v. Minnesota, 309 U.S. I57 (I940).

17 Dixie Ohio Express Co. v. State Revenue Com'n, 306 U.S. 72 (I939); Southern Pacific Co. v. Gallagher, 306 U.S. I67 (I939).
${ }^{88} 304$ U.S. 307 (I938).
39 Ibid., at 327 .
${ }^{20} 305$ U.S. 434 (I939). 
retaliatory burdens imposed by the States. It is of equal importance, however, that the judicial department of our government scrupulously observe its constitutional limitations and that Congress should adopt a broad national policy of regulation-if otherwise valid state laws combine to hamper the free flow of commerce.ax

The most recent expression of these views is in the dissenting opinion in McCarroll v. Dixie Greyhound Lines, ${ }^{22}$ in which-it is important to noteBlack was joined by Justices Frankfurter and Douglas. This case concerned an Arkansas tax imposed on each gallon of gasoline, above twenty, brought into the state by motor vehicles for use as fuel in such vehicles. The proceeds of the tax were allocated for use in highway maintenance. In the particular case the tax was applied to gasoline carried by interstate motor busses for use as fuel in the course of an interstate journey. The majority ruled the tax unconstitutional, refusing to accept the contention that it was a tax on the privilege of using the highways. The three dissenters thought it could reasonably be considered such a tax, since it reached busses and trucks, which caused the heaviest wear on the roads. They were of the opinion, however, that such considerations should be for the legislative branch-the Court "has but a limited responsibility in that state legislation may here be challenged if it discriminates against interstate commerce or is hostile to the congressional grant of authority." ${ }_{23}$ Federal action is necessary to bring about appropriate uniformity in the regulation of interstate commerce. But courts are not equipped to do the task. The problem is for Congress.

Unconfined by "the narrow scope of judicial proceedings" Congress alone can, in the exercise of its plenary constitutional control over interstate commerce, not only consider whether such a tax.... is consistent with the best interests of our national economy, but can also on the basis of full exploration of the many aspects of a complicated problem devise a national policy fair alike to the States and our Union. Diverse and interacting state laws may well have created avoidable hardships. .... But the remedy, if any is called for, we think is within the ample reach of Congress. ${ }^{24}$

$2 x$ Ibid., at 455 .

${ }^{22} 309$ U.S. 176 (1940). 23 Ibid., at I84.

24 Ibid., at 189 . Black voted with the majority in the remaining tax cases, in all of which (except Collins v. Yosemite Park \& Curry Co., 304 U.S. 5 r8 (19387) the exercise of state power was upheld. See note $x 6$ supra for cases involving the Fourteenth Amendment. State tax laws challenged under the federal commerce power were upheld in: Western Livestock v. Bureau of Revenue, 303 U.S. 250 (1938); Coverdale v. Pipe Line Co., 303 U.S. 604 (1938); Bacon \& Sons v. Martin, 305 U.S. 380 (r939); Puget Sound Stevedoring Co. v. State Tax Com'n, 302 U.S. 9o (I937); McGoldrick v. Berwind-White Co., 309 U.S. 33 (I940); McGoldrick v. Felt \& Tarrant Co., 309 U.S. $7 \circ$ (I940); McGoldrick v. Compagnie Générale Transatlantique, 309 U.S. $43^{\circ}$ (1940). A Hawaii tax, challenged under the commerce clause and the Fifth Amendment, was upheld in Inter-Island Steam Navagation Co. v. Hawaii, 305 U.S. 306 (1938), with Black writing the majority opinion. 
Thus, while Black's position on state power seems Jeffersonian, and his insistence upon Congress' "plenary constitutional control over interstate commerce" may seem Hamiltonian, this paradox may be explained by the Justice's understanding that problems of commerce (i.e., economic life) are indeed national and that the Constitution provides the Congress with power to deal with them.

Not only does Black seek to point out the limits of the commerce clause restrictions on state activity, but he has also developed very clear views on the application and scope of the Fourteenth Amendment as a restriction on state regulations of corporate activities. ${ }^{25}$ Black's disagreement with the majority on this point has been on two levels. First, he does not believe that the Fourteenth Amendment should apply to corporations at all; and in this view he continues to stand alone. Second, he believes that even if the Fourteenth Amendment is to be used to protect corporations, it should not furnish a basis for such extensive judicial review as has heretofore obtained. In Connecticut General Life Ins. Co. v. Johnson ${ }^{26}$ Black sets forth his view that the Fourteenth Amendment does not apply to corporations. In that case the Court invalidated a California corporate franchise tax, levied on the privilege of doing business in the state and measured by gross premiums, as applied to an insurance company effecting reinsurance outside the state. Dissenting, Black thought that the corporate franchise tax had not been proved "beyond all reasonable doubt" to violate the Federal Constitution-i.e., that the majority of the Court was carrying the process of judicial review too far-and that the state supreme court should therefore be sustained. He went beyond this, however, and took occasion to strike directly at one of the commonly accepted postulates regarding the due process clause of the Fourteenth Amendment. He denied that the word "person" in that amendment included corporations within the sphere of its operation. "Neither the history nor the language" of the provision, he said, justifies the inclusion of corporations within its protection. ${ }^{27}$ Historically, the Fourteenth Amendment "followed the freedom of a race from slavery." Taking the language of the amendment, he showed how the word "person" as used in other

25 The contract clause has become a less important restriction on state activity in recent years. Wright, The Contract Clause of the Constitution (1938). In Indiana ex rel. Anderson v. Brand, 303 U.S. 95 ( 1938 ), Black wrote a unanimous opinion holding that Indiana legislation affecting teachers' tenure was not invalid under the contract clause.

${ }^{26} 303$ U.S. 77 (1938).

27 Ibid., at $85-86$. For a discussion as to whether the history of the provision justifies application of the amendment to corporations, see McLaughlin, The Court, the Corporation, and Conkling, 46 Am. Hist. Rev. 45 (October, r940). 
phrases of the same article could not mean "corporation." ${ }_{28}$ Yet in the first fifty years after its adoption, in only one-half of one per cent of the cases was the amendment invoked for the protection of Negroes, while in more than fifty per cent it was extended to corporations. "If the people of this nation," concluded Black,

wish to deprive the states of their sovereign rights to determine what is a fair and just tax upon corporations doing a purely local business within their own state boundaries, there is a way provided by the Constitution to accomplish this purpose. That way does not lie along the course of judicial amendment to that fundamental charter. An Amendment having that purpose could be submitted by Congress as provided by the Constitution. I do not believe that the Fourteenth Amendment had that purpose, nor that it should be construed as having that purpose.29

As in state tax legislation cases, so in state police power cases Black has sought generally to uphold the power of the state to legislate with regard to its local industries. In a suit to enjoin the enforcement of a Florida statute providing for the marking and labeling of canned citrus fruit products, the federal district court dismissed the bill upon motion to dismiss, and consequently without hearing the evidence. The Supreme Court, in a short per curiam opinion, ${ }^{30}$ reversed the decree and remanded the case for trial, stating that the allegations in the plaintiff's bill were sufficient to call the constitutionality of the statute into question under the Fourteenth Amendment and that the district court should have heard the evidence. For Black the presumption in favor of the constitutionality of state legislation was so strong, ${ }^{3 \mathrm{x}}$ and the general economic background of the particular legislation-a matter of such common knowledge that the Court might take judicial notice of it-so persuasive, as to render the possibility of the plaintiff's adducing evidence to show unconstitutionality so remote that there was no justification for the delay caused by sending the suit back for trial.

This presumpticn in favor of state legislation - to be noted particularly in matters relating to taxation and the regulation of economic affairsdoes not extend, however, to legislation which is challenged as restricting civil liberties. ${ }^{32}$ It is significant that of the eleven instances in which Black

${ }^{28}$ Section $x$ refers to "all persons born or naturalized." Section 2 declares that representatives shall be apportioned according to the whole number of "persons" in each state, excluding Indians not taxed. Section 3 provides that no "person" who engaged in insurrection could be a Senator or Representative. Could corporations, Black asked, have been meant by the word "person" in any of these provisions?

${ }^{29}$ Connecticut Gen'l Life Ins. Co. v. Johnson, 303 U.S. 77, 90 (I938).

${ }^{30}$ Polk Co. v. Glover, 305 U.S. 5 (I938).

${ }^{3 x}$ Ibid., at 16 . See also Mayo v. Lakeland Highlands Canning Co., 309 U.S. 3 ro (r940). ${ }^{32}$ Cf. Schneider v. State, 308 U.S. $x_{47}$, I55, 162, I63 (1939). 
has voted to invalidate state laws, nine were cases voiding statutes involving restrictions on civil liberties. Two of these concerned anti-picketing ordinances, ${ }^{33}$ and three others concerned licensing of circular and handbill distribution. ${ }^{34}$ True, his record on civil liberties is little different from that of other members of the Court, but in view of his hesitancy to invalidate other kinds of state legislation under the Constitution, it is of added significance that he should do so here. There is nothing in Black's record to deny that the Fourteenth Amendment, in this respect at least, is an important limitation on state action. And it is interesting to note, in view of some of the less responsible charges which have been made against Black, that his record on cases involving Negroes will bear the most severe scrutiny. He has been with the majority in several cases protecting Negroes from the unequal operation of state laws and judicial procedure. ${ }^{35}$ And in Chambers v. Florida $a^{36}$ he wrote the opinion of the Court reversing the convictions of murder obtained against four Negroes on the basis of confessions secured by five days of questioning and coercion. The methods revealed by the record, he said, were unnecessarily harsh.

Today, as in ages past, we are not without tragic proof that the exalted power of some governments to punish manufactured crime dictatorially is the handmaid of tyranny. Under our constitutional system, the courts stand against any winds that blow as havens of refuge for those who might otherwise suffer because they are helpless, weak, outnumbered, or because they are non-conforming victims of prejudice and public excitement. 37

33 Thornhill v. Alabama, 3 ro U.S. 88 (r940), and Carlson v. California, 3 Io U.S. Io6 (I940). The only two instances in which Black voted to invalidate state action, aside from civil liberties cases, were Collins v. Yosemite Park \& Curry Co., 304 U.S. 5 I8 (r938), and Hale v. Bimco Trading Co., 306 U.S. 375 (r939). In the latter case he voted with the Court in an opinion written by Justice Frankfurter, ruling that a Florida statute requiring the inspection of imported cement, imposed too high a fee and constituted an unlawful discrimination against interstate commerce.

${ }^{34}$ Lovell v. Griffin, 303 U.S. 444 (I938); Hague v. CIO, 307 U.S. 496 (I939); and Schneider v. State, 308 U.S. I47 (1939). See also Cantwell v. Connecticut, 3 Io U.S. 296 (I940). But cf. Minersville School District v. Gobitis, 310 U.S. 586 (I940), where a flag-salute law was upheld in the face of a claim for protection of freedom of conscience and religion under the due process clause of the Fourteenth Amendment. Black voted with the majority.

35 Hale v. Kentucky, 303 U.S. 613 (r938); Missouri ex rel. Gaines v. Canada, 305 U.S. 337 (I938); Lane v. Wilson, 307 U.S. 268 (r939). These cases involved, respectively, the exclusion of Negroes from the jury list, the failure to provide a legal education for Negroes in the institutions of the state, and a discriminatory election registration law. Black himself wrote the majority opinion in Pierre v. Louisiana, 306 U.S. 354 (I939), holding that the exclusion of Negroes from the grand jury was a denial of a constitutional right.

${ }^{36} 309$ U.S. 227 (I940). See also White v. Texas, 3 Io U.S. 530 (I940), in which Black's majority opinion is based on the Chambers case.

37 Ibid., at $24 x$. 
It is true that the views entertained by Justice Black with regard to the application and scope of the Fourteenth Amendment in cases involving corporations and with regard to an implied limitation in the commerce clause on the taxing powers of the states have not found acceptance in the majority opinions of the Court. However, the shift in attitude by the Supreme Court with regard to intergovernmental tax immunity is an important instance of the acceptance by the majority of the views first expressed in concurring opinions by Black. Soon after he had commenced his duties, the Court rendered an important decision in two cases argued and decided together. ${ }^{38}$ It was held that a state tax on the gross receipts of a contractor, derived from a contract with the United States, did not constitute a burden on a federal instrumentality and was a valid exercise of the state taxing power. This was a five-to-four decision. Justices Roberts, McReynolds, Sutherland and Butler, dissenting, ${ }^{39}$ felt that strict application of the old doctrine of intergovernmental tax immunity required the voiding of such a state tax. Chief Justice Hughes wrote the majority opinion in this case. Black voted with the majority, without, as yet, expressing any individual views on the matter. ${ }^{40}$ Shortly afterward, the Court in two cases upheld the application of the federal income tax to persons claiming immunity by reason of connection with state governments. In Helvering $v$. Therrell ${ }^{4}$ the application of the income tax to persons hired in the liquidation of a corporation by state officers was upheld by a unanimous court. In Helvering v. Mountain Producers Co. ${ }^{42}$ the application of the federal income tax to a lessee of state school lands was ruled valid. Chief Justice Hughes wrote the opinion, with Justices McReynolds and Butler dissenting. In both these cases Black voted with the majority without undertaking to express his views.

When the important case of Helvering v. Gerhardt $t^{43}$ arose, however, Black no longer contented himself with silent acquiescence. In this instance he again agreed with the decision of the majority, but for the first time took occasion to attack the time-worn formula that while "non-

${ }^{38}$ James v. Dravo Contracting Co., 302 U.S. 134 (1937), and Silas Mason Co. v. Tax Com'n, 302 U.S. I 86 (1937).

39302 U.S. 134,161 (1937).

$4^{\circ}$ The following year, in Atkinson v. Tax Com'n, 303 U.S. 20 (I938), the Court ruled in a per curiam opinion that the Oregon income tax on persons working on the Bonneville Dam, being built by contract with the United States, constituted no burden on a federal instrumentality. In Helvering v. Bankline Oil Co., 303 U.S. 362 (r938), a federal tax on the profits of a lessee of state oil lands was upheld as not interfering with a state instrumentality. Black was silently with the Court in both these cases.

${ }^{4} 303$ U.S. 218 (I938).

${ }^{42} 303$ U.S. 376 (1938).

${ }^{43} 304$ U.S. 405 (1938). 
essential" government activities could be taxed by the other government, "essential" functions could not be so taxed. The case involved a federal tax on the salary of employees of the Port of New York Authority. Justice Stone, writing the majority opinion, upheld the application of the tax on the basis of the usual formula, finding that such a tax did not impede any "essential" state function. Black, while concurring 44 in the result that the tax was valid, went beyond the majority opinion and urged that the Court should now reconsider Collector v. Day, ${ }^{45}$ the leading precedent for intergovernmental tax immunity. The Constitution, he asserted, gave no implied immunity to either state or federal government from taxation by the other. Any judicial attempt to impose such immunity-except within'the broad limits set by the discrimination test-was therefore not only without constitutional foundation, but clumsy in practice. Discussing the usual "essential governmental function" formula, Black remarked:

Conceptions of "essential governmental functions" vary with individual philosophies. . . . The genius of our government provides that within the sphere of constitutional action, the people - acting not through the courts but through their elected legislative representatives-have the power to determine as conditions demand what services and functions the public welfare requires..$^{6}$

At the same term a federal admission tax as applied to the football games of a state university was upheld in a majority opinion written by Justice Roberts, who applied the old formula. ${ }^{47}$ Black again indicated a concurrence with the result only. Justices McReynolds and Butler dissented.

This gradual shift in attitude, noticeable first in a loose application of the old "essential function" criterion,,$^{8}$ and later in the separate concurrences of Justice Black, reached its climax in Graves v. Neze York ex rel. $O^{\prime} K e$ eef ${ }^{49}$ Here Justice Stone not only wrote the majority opinion upholding ' state income tax on a federal employee, but adopted the suggestion made by Black a scant year earlier ${ }^{50}$ to overrule the sixty-eight-yearold precedent of Collector v. Day. Hence, in a short space of time the view of Black, expressed first in a separate concurring opinion, had become essentially the view of the majority. As a fitting epilogue to this

44 Ibid., at 424. 45 II Wall. (U.S.) II3 (I87I).

${ }_{4}^{6}$ Helvering v. Gerhardt, 304 U.S. 405, 426-27 (1938).

47 Allen v. Regents, 304 U.S. 439 (I938).

${ }_{4}^{8}$ The dissents of Justices Roberts, McReynolds, Butler, and Sutherland in James v. Dravo Contracting Co., 302 U.S. I34 (x937), and of Justices McReynolds and Butler in Helvering v. Mountain Producers Corp., 303 U.S. 376 (1938), and Helvering v. Gerhardt, 304 U.S. 405 (1938), point out the departure from the former applications of the criterion.

${ }^{49} 306$ U.S. 466 (I939), noted in 6 Univ. Chi. L. Rev. 705 (I939).

50 Note 44 supra. 
line of decisions, Black himself wrote the majority opinion in a case shortly thereafter, ${ }^{5 x}$ ruling, on the basis of the $O^{\prime} K e e f e$ case, that a Utah state income tax on the salaries of Reconstruction Finance Corporation attorneys was constitutional. Thus was accomplished, during Black's first two years on the Supreme Court, a sweeping change in what had seemed to many to be fundamental constitutional doctrine.

The intergovernmental tax immunity cases thus far discussed have dealt only with an implied immunity, heretofore said to exist and to be judicially enforceable because of the nature of the federal system itself. To deny that an implied immunity exists is not to deny that Congress may specifically provide for the tax immunity of one of its agencies. Thus, Black voted with the majority in Pitman v. Home Owners' Loan Corp..$^{52}$ where the Court held that a state tax on mortgage recording was invalid as applied to the HOLC, since Congress had expressly provided that the agency should be immune from taxation.

Limitation upon the extent to which the Supreme Court may give effect to an implied prohibition under the commerce clause; reluctance to apply the Fourteenth Amendment to state laws regulating corporations; impatience with procedural technicalities where the enforcement of state regulatory measures is at stake; refusal to find judicial power to enforce an implied constitutional immunity in intergovernmental tax cases - all are manifestations of a constitutional philosophy which would draw clearer lines between state and national affairs and limit the power of the federal courts to blur those lines. And it is perhaps not entirely coincidence that it was during the early part of Justice Black's term that the Court, in Erie R. Co. v. Tompkins, ${ }^{53}$ took occasion to strike a more direct blow at the power of the federal courts by overruling Swift $v$. Tyson..$^{54}$ While it may be agreed that Justice Black's influence was of minor importance in the Erie case (as compared with that of Justice Brandeis), it is nevertheless significant that Black has expressed a sympathy with the doctrine surpassing even that of his brethren.

Even before the Erie case, Black had given some indication of his position. In a suit on a life insurance policy, the majority of the Court upheld the lower federal court in applying the federal common law rule as to the effect of a presumption..$^{55}$ Black, dissenting, thought that the state rule should have been applied..$^{6}$ In part, his opinion was based upon an objec-

5I State Tax Com'n v. Van Cott, 306 U.S. 5 II (I939). See also Buckstaff Co. v. McKinley, 308 U.S. 358 (1940).

52 308 U.S. 2 I (1939).

53304 U.S. 64 (r938).

54 I6 Pet. (U.S.) I (I842).

ss New York Life Ins. Co. v. Gamer, 303 U.S. I6I (1938). ${ }^{56}$ Ibid., at $I 72$. 
tion to the federal rule itself because of its operation in giving a "jury function" to the judge; but his view is also based upon the notion that the state rule should in any event be controlling. Significantly Black failed to mention the existence of a state statute (set out in brief of counsel) ${ }^{57}$ which might arguably have permitted the application of state law within the doctrine of Swift v. Tyson; a fact which may perhaps be taken to indicate that he did not care to limit the effect of his remarks to the particular case before him.

Since the Erie case, Black has manifested a disposition to give the doctrine a more rigorous application than that given by the majority. In a suit by the United States as guardian of an Indian, for interest on taxes erroneously collected by a Kansas county, the majority held that interest should be denied, but refused to apply the Kansas law..$^{8}$ Black, concurring in the denial of interest, objected to the majority's reasoning, stating that he concurred "because the laws of Kansas deny interest on tax refunds. ....."

Finally, it was Justice Black who wrote the opinion in a recent case ${ }^{60}$ which apparently gives a considerable extension to the doctrine of Erie $v$. Tompkins. In a bankruptcy litigation in a federal court, a dispute arose regarding the title to certain land held by the bankrupt estate. Under the Erie case, state law would supposedly have been applied by the federal court; but because there was no settled state law on the question in dispute, Justice Black held for a unanimous court that the local nature of the matter required that it actually be sent to the state courts for decision. Thus was effected an even more complete separation between state and national affairs than was envisaged in the Erie case. ${ }^{6 r}$

\section{RELATION BETWEEN COURTS AND OTHER AGENCIES OF GOVERNMIENT}

The cases discussed above demonstrate Justice Black's belief that a federal system functions best when there is a clear separation between state and national activities; that as an aid to this separation of activities, federal courts must exercise restraint in dealing with the activities of state

57 Mont. Rev. Code Ann. (Anderson, 1935) § ro600, cited in Brief of Respondent, at 69, New York Life Ins. Co. v. Gamer, $3^{\circ} 3$ U.S. x6I (1938).

${ }^{8}$ Board of County Com'rs v. United States, 308 U.S. 343 (r939). Cf. Pullman Co. v. Jenkins, 305 U.S. 534, 542, 547-48 (1939).

59 308 U.S. $343,353,355$ (I939).

${ }^{60}$ Thompson v. Magnolia Petroleum Co., 309 U.S. 478 (r940), noted in 7 Univ. Chi. L. Rev. 727 (r940).

${ }^{6 x}$ See 7 Univ. Chi. L. Rev. 727 (I940). 
legislatures. Justice Black's insistence upon narrowing the operation of federal court review does not arise alone, however, from his desire for a clear separation between state and national activities. It arises also from his belief that since it is the legislative and administrative bodies who are responsible to the people in a representative government, the preservation of the representative nature of the government requires that the courts, simply because they are courts rather than legislative or administrative bodies, limit the scope of their review of state administrative matters, national administrative activity, and national legislation.

In the sphere of public utility regulation by state administrative bodies, Black's objections to the prevailing scope of judicial review are closely analogous to his views in dealing with the validity of state statutes. Admitting, of course, that administrative regulations are subject to review under traditional concepts of procedural due process, he denies that the Fourteenth Amendment furnishes authority for the federal courts to indulge in judicial rate-making under notions of substantive due process. Even where Black has admitted the power to review, he has disagreed with the scope of the review granted. For the majority the case of McCart v. Indianapolis Water $C_{0}{ }^{62}$ could be decided temporarily by a short per curiam opinion sending the case back to the district court for retrial on the question of confiscation in view of the change in economic conditions which had occurred between the time of the taking of evidence and the rendering of the decree. For Black the litigation provided the opportunity to set down, in one of his first written opinions on the Court, his views with regard to the function of the federal courts in dealing with the intrastate utility problem and the general problem of valuation and rate-making. ${ }^{63}$ In the first place, in the absence of any allegation by the company of lack of procedural due process in its dealings with the state commission, Black objected to any review by the federal courts. Noting that the Indianapolis Water Co. was a single company located within a single state, he remarked, "I believe that the State of Indiana has the right to regulate the price of water in Indianapolis free from interference by federal courts." ${ }^{\prime \prime}$

For the first hundred years of this Nation's history federal courts did not interfere with state legislation fixing maximum rates for public services performed within the respective states. The state legislatures, according to a custom which the Court declared had existed "from time immemorial" decided what those maximum rates should be. This Court also said that "for protection against abuses by legislatures the people must resort to the polls, not to the courts." It was not until x890 that a divided court finally repudiated its earlier constitutional interpretation and declared that due

$$
{ }_{62}^{6} 302 \text { U.S. } 4 \text { I9 (I937). } \quad 6_{3} \text { Ibid., at } 423 . \quad{ }_{4}^{6} \text { Ibid., at } 44 \mathrm{I} \text {. }
$$


process of law requires judicial invalidation of legislative rates which the courts believe confiscatory. The dissenting justices adhered to the long existing principle that regulation of public utilities was a "legislative prerogative and not a judicial one." 65

In the second place, even assuming that review was proper, Black objected to the procedure employed by the majority. The litigation had begun in $\mathrm{I} 93 \mathrm{I}$; in I937 it was to be returned for consideration "anew." In view of the "almost insuperable obstacles to rate regulation," "he warned that the case would keep shuttling back and forth until the Supreme Court handed down a definitive decision; that the only function of the Court was to decide the issue of confiscation, and that there was ample material in the record to indicate that there was no confiscation.

In Uniled Gas Co. v. Texas ${ }^{67}$ he again disagreed with the reasoning of the Court in a utility rate case. The Court ruled that a rate fixed by the Texas Railroad Commission was no violation of due process. Black, concurring, took occasion to stress his view that the function of the Court is limited to a review of the procedural due process. ${ }^{68}$ Applying this view to the particular case, he quoted an 1877 opinion to the effect that

it is not possible to hold that a party has, without due process of law, been deprived of his property, when, as regards the issues affecting it, he has, by the laws of the State, a fair trial in a court of justice, according to the modes of proceeding applicable to such a case. ${ }^{69}$

Not only, therefore, has Black declined to find any of the rate orders before the Court confiscatory, but he has gone on record as favoring a reinterpretation of the Fourteenth Amendment narrowing the scope of review of the federal judiciary over the actions of state administrative agencies.

In the sphere of federal administrative action, Black's record is consistent with his general attitude of respect for the practical problems facing legislative and administrative bodies. In the twenty-six cases before the Court involving federal administrative action, during the three years the majority has on five occasions reversed an administrative ruling. ${ }^{70}$ In every one of these five cases Black dissented. In one case he

65 Ibid., at 427-28.

${ }^{66}$ Ibid., at 435 .
${ }^{6}{ }_{3} 03$ U.S. I23 (1938).

${ }^{68} \mathrm{Ibid} .$, at $\mathrm{I} 46$.

69 Ibid., at I53, quoting Davidson v. New Orleans, 96 U.S. 97, I05 (1877). Cf. Driscoll v. Edison Light \& Power Co., 307 U.S. I04 (I939), where the majority upheld a Pennsylvania temporary rate statute, on the ground that the state commission, in applying the statute, had used the "rule of Smyth v. Ames." Justices Frankfurter and Black, concurring, stated that the procedure as set forth in the statute was adequate.

${ }^{70}$ Morgan v. United States, 304 U.S. I (1938); Consolidated Edison Co. v. NLRB, 305 U.S. I97 (1938); NLRB v. Columbian Enameling \& Stamping Co., 306 U.S. 292 (I939); 
dissented without opinion, ${ }^{7 x}$ in two others he concurred in a dissenting opinion written by Justice Reed, ${ }^{72}$ and in still another he and Reed dissented without specific opinions. ${ }^{73}$ It is in his own dissenting opinion in $N L R B$ v. Columbian Enameling \& Stamping Co. ${ }^{74}$ that one finds the first expression of Black's opinions with regard to the relationship of the Court to federal administrative agencies. The National Labor Relations Board had issued an order demanding the reinstatement of certain employees found to have been discharged in violation of the National Labor Relations Act. The majority of the Court reversed the order, finding the evidence insufficient to support it. Black dissented, pointing out that the act provides that "findings of the Board as to the facts, if supported by evidence, shall be conclusive."75 Accepting this as a real limitation on the power of the courts to review, meaning that "courts should not-as heresubstitute their appraisal of the evidence for that of the Board," Black stated that

the Labor Board, the Federal Trade Commission, the Interstate Commerce Commission, the Securities and Exchange Commission, and many other administrative agencies were all created to deal with problems of regulation of ever increasing complexity in the economic fields of trade, finance and industrial conflicts. Congress thus sought to utilize procedures more expeditious and administered by more specialized and experienced experts than courts had been able to afford. The decision here tends to nullify this Congressional effort. ${ }^{76}$

In his first two years on the bench, Black wrote only one majority opinion dealing with administrative law. ${ }^{77}$ Of eleven such cases before the Court in the 1939 term, however, Black wrote the opinion of the Court in five. ${ }^{78}$ In these opinions, and particularly in $N L R B$ v. Waterman Steamship Corp. ${ }^{79}$ and $N L R B$ v. Bradford Dyeing Ass' $n,{ }^{80}$ he elaborated his

NLRB v. Fansteel Metallurgical Corp., 306 U.S. 240 (I939); and NLRB v. Sands Mfg. Co., 306 U.S. 332 (r939). Cf. National Licorice Co. v. NLRB, 309 U.S. 350 (1940), and American Mfg. Co. v. NLRB, 309 U.S. 629 (I940), involving partial modification of board orders. Black also dissented in these cases, along with Justice Douglas.

7I Morgan v. United States, 304 U.S. I, 22 (1938).

${ }^{2}$ Consolidated Edison Co. v. NLRB, 305 U.S. I97, 244 (I938); NLRB v. Fansteel Metallurgical Corp., 306 U.S. 240, 265 (1939).

${ }^{7}$ NLRB v. Sands Mfg. Co., 306 U.S. 332, 346 (r939).

${ }^{74} 306$ U.S. 292, 300 (I939).

75 Ibid., at 3 or. $\quad{ }_{76}^{6} \mathrm{Ibid}$.

77 FTC v. Standard Education Society, 302 U.S. II2 (I937).

${ }^{8}$ Helvering v. Lazarus, 308 U.S. 252 (1939); NLRB v. Falk Corp., 308 U.S. 453 (1940); NLRB v. Waterman Steamship Corp., 309 U.S. 206 (I940); NLRB v. Bradford Dyeing Ass'n,

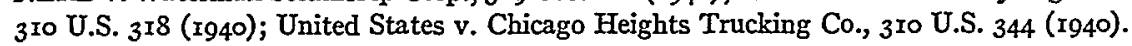

${ }^{79} 309$ U.S. 206 (1940).

${ }^{80}$ 3 тo U.S. 3 I8 (I940). 
position that administrative findings of fact supported by evidence which permits, at most, conflicting inferences are conclusive upon review by the courts. ${ }^{8 \mathrm{I}} \mathrm{He}$ insisted that: "The proper working of the scheme fashioned by Congress to determine industrial controversies fairly and peaceably demands that the courts quite as much as the administrative body act as Congress has required."

As to the role of the federal courts with regard to national legislative activity Black has had little occasion to deviate from the views of the majority, since in every one of the twenty-eight cases in this three-year period involving the validity of a federal statute the law was sustained..$^{8_{3}}$ He has not directly expressed his individual views on such questions as the due process clause of the Fifth Amendment, the federal taxing power, or the delegation of legislative powers to the executive. On this last point, however, there is some evidence that he may be prepared to announce views somewhat different from those of the majority. In all cases in which the charge of unconstitutional delegation was made, the Court deemed it ill-founded and Black agreed. It is perhaps significant, however, that in Shields v. Utah Idaho Central R. Co. ${ }^{84}$ Black concurred in the result only, without expressing his reasons, but presumably reserving acceptance of the views advanced by the majority opinion in support of that result. In view of his use of this technique in preparing the way for his remarks on intergovernmental tax immunity and on state public utility regulation, one might expect to hear, as soon as the occasion calls for it, an exposition of the views of Justice Black on the doctrine of the separation and nondelegation of legislative powers..$^{85}$

Although Black has not, in litigation directly involving acts of Con-

${ }^{8 x}$ Cf. Helvering v. Lazarus, 308 U.S. 252, 255 (1939); NLRB v. Falk Corp., 308 U.S. 453, $46 \mathrm{~T}(\mathrm{x} 940)$.

${ }^{82}$ NLRB v. Bradford Dyeing Ass'n, 3ro U.S. 3I8, 343 (I940).

${ }^{83}$ There is not space here to list all of the cases involving the validity of a federal statute. Suffice it to say that Black was with the majority in all of them, and himself wrote the opinion of the Court in the following cases: McNair v. Knott, 302 U.S. 369 (1937); Guaranty Trust Co. v. Henwood, 307 U.S. 247 (r939); Kalb v. Feuerstein, 308 U.S. 433 (I940); Perkins v. Lukens, 3 Io U.S. II3 (r940); United States v. San Francisco, 310 U.S. I6 (I940).

${ }^{84} 305$ U.S. I77 (x938).

85 Black's use of this device in the tax immunity cases is discussed supra, pp. 29-3I. In the public utility cases, the dissent in McCart v. Indianapolis Water $\mathrm{Co}$. and the concurring opinion in United Gas. Co. v. Texas were preceded by a concurrence without opinion in Railroad Com'n v. Pacific Gas \& Electric Co., 302 U.S. 388 (r937). See supra, pp. r34-35. For other separate concurrences see Alabama Power Co. v. Ickes, 302 U.S. 464 (I937); Duke Power Co. v. Greenwood County, 302 U.S. 485 (I937); Adam v. Saenger, 303 U.S. 59 (I938); United States v. Carolene Products Co., 304 U.S. I44 (1938); Ford Motor Co. v. Beauchamp, 308 U.S. 33 I (1939); Allen v. Regents, 304 U.S. 439 (I938). 
gress, set forth his views as to the relationship between federal courts and Congress, he has, in a somewhat different situation, clearly indicated that his position on this question is much the same as the position more clearly expressed in other types of litigation. In Coleman v. Miller ${ }^{86}$ the question before the Court was whether previous rejection by the Kansas legislature of the Child Labor Amendment to the Federal Constitution precluded subsequent ratification, and whether an unreasonable time had elapsed since the submission of the amendment to the states for ratification. Mandamus proceedings had been brought by members of the Kansas legislature to compel a "proper record" of legislative action on the amendment. The Court, speaking through the Chief Justice, ruled this a "political" question, stating that the decision of Congress on whether the amendment was properly ratified would be made at the time of promulgation and would not be reviewable by the courts. The majority opinion failed, however, expressly to overrule Dillon v. Gloss, ${ }^{87}$ which held that ratification must be within a reasonable time. Protesting this implication that the judiciary might still exercise some control over the amending process and urging that it was entirely up to Congress to determine whether the amendment had been properly passed, Black wrote a concurring opinion in which he urged that the Constitution give no justification for any review whatever, that the matter was entirely a political one, and that

any judicial expression amounting to more than mere acknowledgement of exclusive Congressional power over the political process of amendment is a mere admonition to Congress in the nature of an advisory opinion, given wholly without constitutional authority. ${ }^{88}$

\section{"JUDICLAI TEMPERAMENT"}

One of the arguments most frequently used in opposing the confirmation of Hugo Black as Associate Justice of the Supreme Court was that he was lacking in "judicial temperament."89 The term was not carefully defined, but it was commonly said that while Black might be a statesman, a capable legislator, and an able politician, his temperament and personal

${ }^{86}{ }_{307}$ U.S. 433 (1939). ${ }^{87} 256$ U.S. 368 (I92x).

${ }^{88}$ Coleman v. Miller, 307 U.S. 433, 456 ( 9939 ). See also Chandler v. Wise, 307 U.S. 474 (1939), in which it was sought to restrain Governor Chandler from sending in a certificate of ratification of the Child Labor Amendment by the Kentucky legislature, on the ground that the ratification was void because Kentucky had previously rejected the amendment. The Chief Justice ruled that this was "no longer a controversy susceptible to judicial determination." Black concurred separately, on his reasoning in Coleman v. Miller.

${ }^{89} 8$ I Cong. Rec. 9075, 9087, 9097 (1937). Senator Burke in the course of the debate called into doubt Black's "attributes of fairness, tolerance and impartiality along with judicial poise and temperament" necessary for a Justice of the Supreme Court. 8r Cong. Rec. 907I (I937). 
qualities fitted him to be an advocate rather than a judge. The implication was that on the bench he would be unable to throw off his partisanship touching the issues with which he had dealt as a legislator. (Those who supported the nomination were quick to remind the country that this criticism had been made of Louis D. Brandeis at the time of his appointment.90) Without attempting to define the term "judicial temperament";" without determining whether such "judicial temperament" constitutes a sine qua non for a member of a court passing on broad issues of public policy; and without laboring the point that many of our greatest judges from Marshall through Brandeis were considered lacking in this quality by many contemporaries, it is proposed here to explore further Black's attitude toward the work of the Court and to consider whether that attitude has changed during his three years on the bench.

Black's early opinions served, in the minds of many, to substantiate the charge. With each dissenting or concurring opinion, it became increasingly clear that those same views which had been expressed by Senator Black as to the proper Constitutional function of the judiciary were still entertained by Justice Black on the Court. Sometimes these views were expressed in forthright attacks upon longstanding "principles": the interpretation of the Fourteenth Amendment empowering courts to extend the same protection to corporations as to "persons"; the judiciallyenforceable immunity against state taxation of interstate commerce; the implied immunity against intergovernmental taxation. Sometimes the views took the form of objections to time-consuming procedural devices: the returming of $\mathrm{McCart} v$. Indiananapolis Water $\mathrm{Co}^{92}$ for consideration "anew" after six years of litigation; the returning of Polk v. Glover ${ }^{93}$ to the district court when the record and common knowledge of the judges

${ }^{90}$ See Lief, Brandeis $348-49,377$ (1936). Note also Senator Ashurst's remarks on the parallel between this type of opposition both to Justice Brandeis and to Black. 8I Cong. Rec. 9099, 9100 (r937).

9x Consider, however, the remarks of Circuit Judge Sanborn in United States v. TransMissouri Freight Ass'n, 58 Fed. 58, 69 (C.C.A. 8th 1893 ): "In considering [public policy], we [judges] are not to be governed by our own views of the interests of the people, or by general considerations tending to show what policy would probably be wise or unwise. Such a standard of determination might be unconsciously varied by the personal views of the judges who constitute the court. The public policy of the nation must be determined by its constitution, laws, and judicial decisions. So far as they disclose it, it is our province to learn and enforce it; beyond that it is unnecessary and unwise to pursue our inquiries."

92302 U.S. 4I9 (1937). Black's attitude in this case may be compared with his views expressed in State Tax Com'n v. Van Cott, 306 U.S. 5 II (I939). In that case Black, writing for the majority, found a federal question to support Supreme Court review of the state court's decision, although it appeared that the state court had relied on a "non-federal" ground. The point is discussed in 39 Col. L. Rev. ro43 (I939).

${ }_{93} 305$ U.S. 5 (1938). 
left little doubt as to the constitutionality of the statute. Sometimes Black's dissents arose from a belief that underlying economic factors were not adequately reflected in the opinions of the majority. In a case ${ }^{94}$ where a bank president and a surety company's agent were fraudulent in issuing "window-dressing" bonds, the surety company was allowed by the majority to raise the defense of fraud against the receiver of the bank, just as it could have against the bank itself. For Black, the banking corporation was not simply a unit; it was made up of an aggregate of interests, in which the creditors represented by the receiver could not be said to be bound by the president's fraud in the same manner as the bank itself would have been. ${ }^{95}$ Again, dissenting in two patent cases, Black took occasion to express the view that since patents are aids to the development of monopoly, courts should construe the patent statutes strictly. In one of the cases, ${ }^{96}$ the majority decision allowed a temporary application, made seven years before, to stand as the basis for granting the patent, thereby increasing the total number of years during which the applicant could control the manufacture of the article. In the other case ${ }^{97}$ the majority upheld a licensing arrangement which greatly increased the patentee's control over the sale of a product. Black, dissenting in both cases, urged that the majority's departure from what he considered a strict construction of the statutes was an unwarranted judicial aid to monopoly..$^{98}$

That a Supreme Court Justice should have definite views as to the meaning of the Constitution and the function of the judiciary thereunder can hardly in itself be termed a lack of "judicial temperament." Since Justice Black's view as to the degree of judicial restraint required by the Constitution differed from the view manifested in the decisions of the Court in the last fifty years, however, the expression of that view necessarily gave the appearance of a lack of respect for precedent. True, precedents were cited by Black, but they were often precedents of fifty or more years before, doctrines which the majority felt had been superseded; or they were a "rival" line of precedents. Whether this insistence upon a different interpretation of the Constitution, and the incidental disregard

94 Deitrick v. Standard Surety Co., 303 U.S. 47 I (I938).

95 Ibid., at 48 r. Cf. 5 Univ. Chi.L. Rev. 296 (x938), noting Deitrick v. Standard Surety Co., 90 F. (2d) 862 (C.C.A. Ist r937).

${ }^{96}$ Crown Cork \& Seal Co. v. Ferdinand Gutmann Co., 304 U.S. 159 (1938).

97 General Talking Picture Corp. v. Western Electric Co., 305 U.S. 124 (I938). Cf. Black's dissenting opinion in a similar copyright case. Washingtonian Publishing Co. v. Pearson, 306 U.S. 30,42 (1939).

${ }_{98}$ Cf. r Lyon, Watkins, Abramson, Government and Economic Life, r32-34 (1939) (résumé of TNEC hearing data on "patent pendency"). 
of precedents, constitutes a lack of judicial temperament depends in the last analysis upon one's view as to whether the Constitution may be reinterpreted, and, if so, whether the Court should effect a change by a single decision or by a gradual process. The tenor of Black's opinions indicates that he would make the change immediately, but in evaluating his position it should be kept in mind that his views are not expressed in majority opinions. The expression of the views in dissenting opinions did not affect the result of the particular case, and it may be doubted whether Black would have effected such a sweeping change if he had been writing a majority decision. Dissenting opinions have a special role in our judicial history; they sometimes express an unpopular, but realistic, view of a case $; 99$ they may point to economic realities; ${ }^{\text {xoo }}$ they may serve as a warning or guide to the future. ${ }^{\text {xox }}$ Furthermore, criticism of Black's position, even from the standpoint that there should be no reinterpretation of the Constitution, must be made in the light of the fact that Black came to the bench at a time when the function of the Supreme Court had just been called seriously into question; when the majority itself had altered its position on some questions. ${ }^{\text {102 }}$

Nevertheless, Black's attitude on the Court has served, for some, to bear out the charges made at the time of his appointment with regard to his temperamental fitness for the bench. Such criticisms, however, have been heard less frequently in the last year. With the changing tendencies and personnel of the tribunal, Black is no longer so spectacularly playing a lone hand. This fact should not be interpreted as indicating any great alteration of his own views. The new members of the Court-particularly Justices Frankfurter and Douglas-have brought new ideas to the group's deliberations; there has been interaction; and the result has been that the majority of his associates now share with Black, or, from another view point, Black shares with his associates, a new attitude. Under these circumstances the Supreme Court itself has tended to replace Mr. Justice Black as the chief object of criticism based on the disregard of alleged constitutional fundamentals. ${ }^{103}$

99 E.g., the dissent of Justice Holmes in Vegelahn v. Guntner, 167 Mass. 92, 104, 44 N.E. I077, 1079 (I896).

${ }^{100}$ E.g., the dissent of Justice Brandeis in New State Ice Co. v. Liebmann, 285 U.S. 262, 306 (I932).

${ }^{101}$ E.g., the concurring opinion of Black in Helvering v. Gerhardt, 304 U.S. 405, 424 (I938). See pp. 29-30 supra.

${ }_{102}$ Viz., NLRB v. Jones \& Laughlin Steel Corp., zor U.S. I (r937); Steward Machine Co. v. Davis, 3 or U.S. 548 (r937).

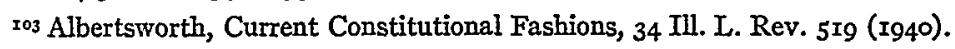




\section{CONCLUSION}

There is probably small likelihood that the Court will adopt Black's views concerning the word "person" in the Fourteenth Amendment, or act upon his suggestion that state public utility commissions and state courts may regulate intrastate utilities without supervision by the federal judiciary, or withdraw from bestowing a close scrutiny upon state police power legislation under the substantive aspect of the due process clause. Perhaps there is little more likelihood that his views with regard to nondiscriminatory state taxation as a "burden" on interstate commerce will find acceptance by the Court. But there is some reason to believe that his general approach to legislative and administrative activity, his insistence that the judiciary leave the choice of means to policy-making agencies, and his distaste for the exercise of a wide judicial veto over other branches of the government, may come to be reflected more and more in the attitude of the majority.

If it is true, as many believe, that democracy to survive must find a means of coping effectively with the issues of present-day civilization, it is likewise true that legislative and administrative agencies responsible to the people must be endowed with a sufficient breadth of action to achieve those ends. The choice of means, within a broad periphery, must lie with those agencies. The degree of freedom to be permitted depends, of course, less on the Constitution itself than on the views of the various judges as to what the Constitution requires or permits. Far more important than particular cases decided individually is the sum of those cases constituting the approach of the judge and the Court to legislative and administrative action in general. It is in this realm of judicial attitude that Mr. Justice Black's constitutional opinions are playing and will continue to play their most significant role. 